\title{
ISOLATION AND CHARACTERIZATION OF CONCANAMYCINS A, B AND C
}

\author{
Haruyasu Kinashi*, Kinumi Someno and Kenji Sakaguchi \\ Mitsubishi-Kasei Institute of Life Sciences \\ Minamiooya, Machida-shi, Tokyo 194, Japan
}

(Received for publication July 31,1984 )

\begin{abstract}
Concanamycins A, B and C were isolated from the mycelium of Streptomyces diastatochromogenes S-45 as effective inhibitors of the proliferation of mouse splenic lymphocytes stimulated by concanavalin A. They represent a new class of 18 -membered macrolide antibiotics, and are biologically active in vitro against several fungi and yeasts, but not against bacteria. Concanamycin $\mathrm{A}$, the main component, has been identified with antifungal antibiotics, folimycin and A-661-I.
\end{abstract}

In the course of screening for immunologically active substances of microbial origin, three antibiotics were isolated from the mycelium of Streptomyces diastatochromogenes S-45 as effective inhibitors of the proliferation of mouse splenic lymphocytes stimulated by concanavalin A. These antibiotics were designated as concanamycins A, B and C according to their biological properties. Using this screening system, we also isolated two other new antibiotics, 2-11-A and B, whose structures have been determined as nonaketide antibiotics ${ }^{1)}$. The present paper describes the screening method, fermentation, isolation, and chemical and biological properties of concanamycins. The structures of concanamycins have been reported recently by us as shown in Fig. $1^{2 \sim 4)}$. They belong to a new class of 18 -membered macrocyclic lactones with a long side chain which incorporates a sixmembered hemiketal ring having 2-deoxy- $\beta$-D-rhamnosyl group as a substituent. Comparison of concanamycins with other related antibiotics is also discussed. As a result of this study, concanamycin $\mathrm{A}$ has been identified with the antifungal antibiotics, folimycin ${ }^{5)}$ and $\mathrm{A}-661-\mathrm{I}^{\mathrm{B})}$, and concanamycins $B$ and $C$ seem to be new antibiotics.

Fig. 1. Structures of concanamycins $\mathrm{A}, \mathrm{B}$ and $\mathrm{C}$, and their $O$-methyl derivatives.

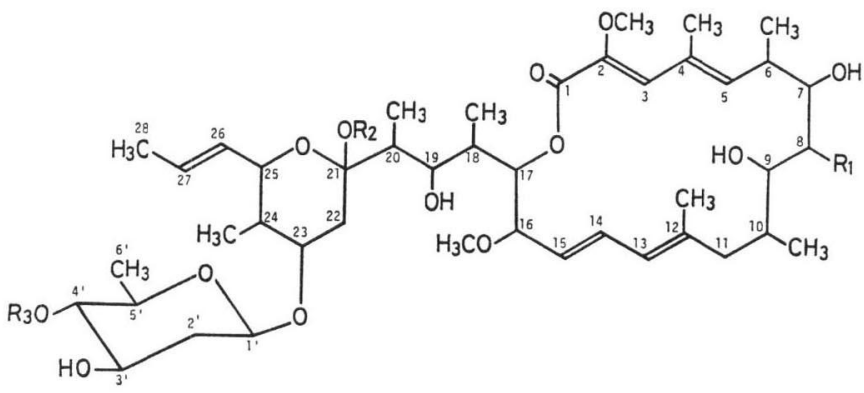

\begin{tabular}{|c|c|c|c|}
\hline & $\mathrm{R}_{1}$ & $\mathrm{R}_{2}$ & $\mathrm{R}_{3}$ \\
\hline Concanamycin A & $\mathrm{CH}_{2} \mathrm{CH}_{3}$ & $\mathrm{H}$ & $\mathrm{CONH}_{2}$ \\
\hline$\| \quad$ B & $\mathrm{CH}_{3}$ & $\mathrm{H}$ & $\mathrm{CONH}_{2}$ \\
\hline$" \prime \quad \mathrm{C}$ & $\mathrm{CH}_{2} \mathrm{CH}_{3}$ & $\mathrm{H}$ & $\mathrm{H}$ \\
\hline$O$-Methylconcanamycin A & $\mathrm{CH}_{2} \mathrm{CH}_{3}$ & $\mathrm{CH}_{3}$ & $\mathrm{CONH}_{2}$ \\
\hline $\begin{array}{ll}\prime \prime & \text { B }\end{array}$ & $\mathrm{CH}_{3}$ & $\mathrm{CH}_{3}$ & $\mathrm{CONH}_{2}$ \\
\hline $\mathrm{C}$ & $\mathrm{CH}_{2} \mathrm{CH}_{3}$ & $\mathrm{CH}_{3}$ & $\mathrm{H}$ \\
\hline
\end{tabular}


Screening Method

Mitogenesis assays were conducted using spleen cells from $d d \mathrm{Y}$ mice cultured under the following conditions. The spleens were minced in small pieces with tweezers in serum-free RPMI 1640 medium, suspended by gentle pipetting, and passed through a Nylon screen to remove the debris. The cells were washed twice with RPMI 1640 by centrifugation at $1,500 \mathrm{rpm}$ for 10 minutes. A total volume of $250 \mu \mathrm{l}$ of cell suspension containing $1 \times 10^{\circ}$ cells was incubated in tissue culture plates in RPMI 1640 supplemented with $20 \mathrm{~mm}$ HEPES ( $N$-2-hydroxyethylpiperazine- $N$ '-2-ethanesulfonic acid, $\mathrm{pH} 7.7$ ), $10 \%$ fetal calf serum, $60 \mu \mathrm{g}$ of kanamycin sulfate, and $4 \mu \mathrm{g}$ of concanavalin A per ml. Before addition of concanavalin A, $5 \mu 1$ of filter-sterilized fermentation broth or its dilution to be assayed was added. Cultures were incubated at $37^{\circ} \mathrm{C}$ in $95 \%$ air $-5 \% \mathrm{CO}_{2}$ atmosphere for 50 hours and pulsed with $0.2 \mu \mathrm{Ci}$ of $\left[{ }^{3} \mathrm{H}\right]$ thymidine for the last 20 hours of incubation period. The cells were harvested on glass filter papers using a cell harvestor, washed with water, and after drying the amount of $\left[{ }^{3} \mathrm{H}\right]-$ thymidine incorporated into the cells was measured in a liquid scintillation counter. In this screening system, the fermentation broth of $S$. diastatochromogenes $\mathrm{S}-45$ was found to inhibit the incorporation of $\left[{ }^{3} \mathrm{H}\right]$ thymidine into the cells.

\section{Fermentation}

The fermentation inoculum $(500 \mathrm{ml})$ was prepared by two stage submerged culture, in a medium consisting of $1 \%$ starch, $1 \%$ Polypeptone, $1 \%$ molasses and $1 \%$ meat extract in tap water (initial pH 7.2). This was transferred into a 30-liter fermentor containing 15 liters of the medium composed of $1 \%$ glucose, $1 \%$ starch, $1.5 \%$ soybean meal, $0.4 \%$ dry yeast, $0.2 \% \mathrm{NaCl}, 0.1 \%$ meat extract and $0.005 \%$ $\mathrm{K}_{2} \mathrm{HPO}_{4}$ (initial pH 8.8). The fermentation was carried out at $27^{\circ} \mathrm{C}$ for 3 days under aeration (10 liters/minute) and agitation (200 rpm). The course of a typical fermentation is illustrated in Fig. 2. Determination of antibiotic activity was made by the method described above and the maximum inhibitory activity in the mycelium was reached after about 70 hours of fermentation.

Fig. 2. Time course of the production of concanamycins in the mycelium of $S$. diastatochromogenes S-45. $\bigcirc$ Packed cell volume $(\%), \square \mathrm{pH}, \triangle$ incorporation of $\left[{ }^{3} \mathrm{H}\right]$ thymidine into mouse splenic lymphocyte cells $(\%)$. The mycelium was extracted with the same volume of $\mathrm{MeOH}$ as that of the fermentation broth, dilutd $10^{3}$ times, and $5 \mu 1$ was added to each well of tissue culture plates.

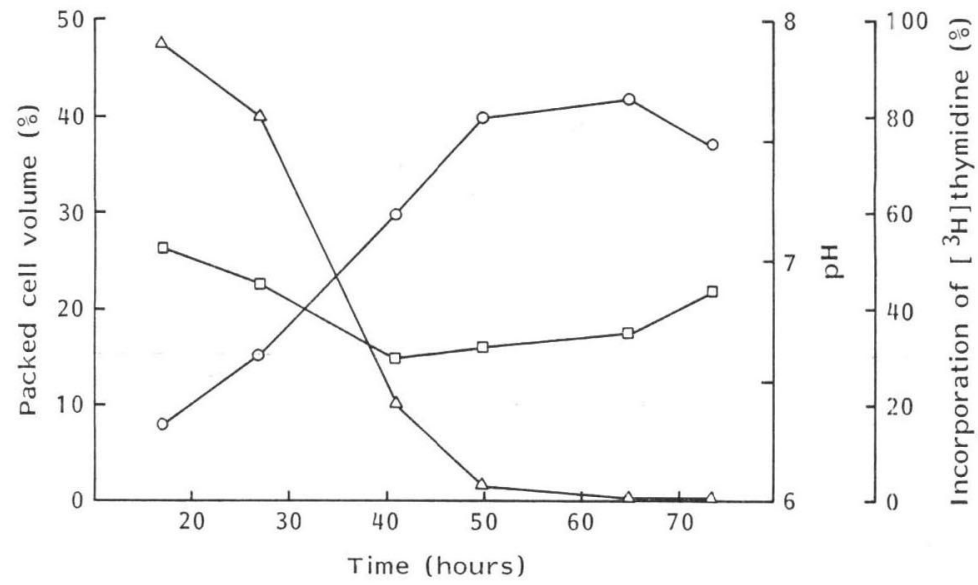




\section{Isolation}

Since the inhibitory activity was mostly present in the mycelium, the mycelial cake was extracted with methanol three times. The extract was concentrated to an aqueous solution, which was extracted two times with ethyl acetate at $\mathrm{pH}$ 8. After washing with water at $\mathrm{pH} 3$, the ethyl acetate extract was evaporated in vacuo to a brown syrup. This was dissolved in benzene and adsorbed on a silica gel column. After washing with benzene and a mixture of benzene and ethyl acetate (1:1) successively, the antibiotics were eluted with ethyl acetate. The crude complex obtained by combination of the active fractions was checked by silica gel HPLC with chloroform and methanol (40:1), indicating the presence of two separable components as shown in Fig. 3a. Standing in $10^{-3} \mathrm{~N} \mathrm{HCl}$ - methanol at room temperature overnight, this crude complex showed three peaks as illustrated in Fig. $3 \mathrm{~b}$. This change of chromatographic behavior proved later to be caused by $O$-methylation of a hemiketal hydroxyl group of three components contained in the crude complex by treating with $\mathrm{HCl}$ - metanol, although concanamycin $\mathrm{C}$ was somewhat difficult to be transformed. O-Methylconcanamycins A and B gave discrete peaks on HPLC with choloform and methanol as shown in Fig. $3 b$, even though the hydroxyl forms could not be separated with any solvent systems tested. Therefore, a mixture of the methylated derivatives were purified by silica gel column chromatography with chloroform and methanol (30:1 and 20:1), and the purified derivatives obtained were respectively converted to their corresponding hydroxyl forms by shaking overnight in a mixture of chloroform and aqueous $0.1 \mathrm{~N} \mathrm{HCl}$. The hydroxyl forms of concanamycins were further purified by silica gel thin-layer chromatography with benzene and ethyl acetate $(1: 4)$, and

Fig. 3. High pressure liquid chromatograms of crude concanamycins before (a) and after (b) treating with $10^{-3} \mathrm{~N} \mathrm{HCl}-\mathrm{MeOH}$.

Conditions: Porasil T, $1 \mathrm{~m} \times 1 \mathrm{~mm}$; $\mathrm{CHCl}_{3}{ }^{-}$ $\mathrm{MeOH}$ (40:1), $3 \mathrm{ml} /$ minute; UV detection at $254 \mathrm{~nm}$.

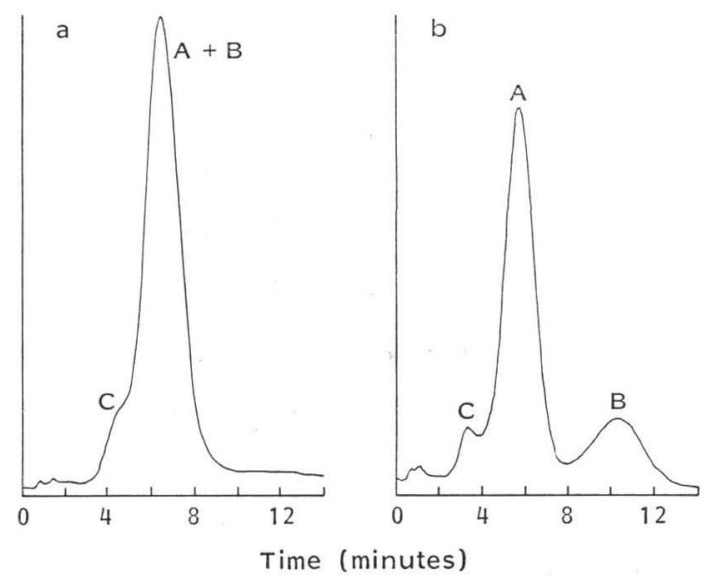
finally by Sephadex LH-20 column chromatography with isopropyl alcohol as developing solvent. The Rf values on silica gel thin-layer of the free hydroxyl and $O$-methyl forms of three components are listed in Table 1.

\section{Chemical Characterization}

Physico-chemical properties of concanamycins A, B and C are listed in Table 2. The UV spectra of these antibiotics indicated in common the presence of an $\alpha, \beta, \gamma, \delta$-unsaturated ester $(285 \mathrm{~nm})$ and a

Table 1. Rf values on silica gel TLC of the free hydroxyl and $O$-methylconcanamycins.

\begin{tabular}{lcccccc}
\hline & A-OH & A-OMe & B-OH & B-OMe & C-OH & C-OMe \\
\hline Solvent 1 & 0.27 & 0.28 & 0.27 & 0.24 & 0.33 & 0.36 \\
Solvent 2 & 0.25 & 0.33 & 0.24 & 0.23 & 0.27 & 0.39 \\
Solvent 3 & 0.18 & 0.23 & 0.18 & 0.16 & 0.28 & 0.35 \\
\hline
\end{tabular}

Solvent $1 \mathrm{CHCl}_{3}-\mathrm{MeOH}(10: 1)$, solvent $2 \mathrm{C}_{6} \mathrm{H}_{6}$ - EtOAc (1:4), solvent $3 \mathrm{CHCl}_{3}-1-\mathrm{PrOH}(10: 1)$. Silica gel $60 \mathrm{~F}-254$ plates (Merck, $10 \mathrm{~cm}, 0.25 \mathrm{~mm}$ ) were used. 
Table 2. Physico-chemical properties of concanamycins.

\begin{tabular}{llll}
\hline & \multicolumn{1}{c}{$\mathrm{A}$} & \multicolumn{1}{c}{$\mathrm{B}$} & \multicolumn{1}{c}{$\mathrm{C}$} \\
\hline Nature & Colorless thin plates & White amorphous powder & \multicolumn{1}{c}{ Colorless thin plates } \\
MP & $162 \sim 163.5^{\circ} \mathrm{C}$ & - & $153 \sim 155^{\circ} \mathrm{C}$ \\
Molecular formula & $\mathrm{C}_{46} \mathrm{H}_{75} \mathrm{NO}_{14}$ & $\mathrm{C}_{45} \mathrm{H}_{73} \mathrm{NO}_{14}$ & $\mathrm{C}_{43} \mathrm{H}_{74} \mathrm{O}_{13}$ \\
MS $(m / z)$ & $865\left(\right.$ in beam EI, M $\left.{ }^{+}\right)$ & $874\left(\mathrm{FD}, \mathrm{M}+\mathrm{Na}^{+}\right)$ & $804\left(\mathrm{EI}, \mathrm{M}^{+}-\mathrm{H}_{2} \mathrm{O}\right)$ \\
$\mathrm{UV} \lambda_{\mathrm{max}}^{2 \mathrm{PrOH}}(\mathrm{nm}, \varepsilon)$ & $245(40,500)$, & $245(38,000)$, & $245(40,800)$, \\
& $285(19,800)$ & $285(18,500)$ & $285(19,700)$ \\
$\mathrm{IR} \nu_{\max }^{\mathrm{CHCl}_{3}}\left(\mathrm{~cm}^{-1}\right)$ & $3560 \sim 3500,3420,1718$, & $3545,3430,1720,1690$, & $3685,3590,3415,1690$, \\
& $1690,1585,1455,1385$, & $1585,1450,1380,1360$, & $1607,1450,1365$ \\
& 1363 & & \\
{$[\alpha]_{\mathrm{D}}^{25}$} & $-21.7^{\circ}(c 1.0, \mathrm{MeOH})$ & $-20.6^{\circ}(c 0.63,2-\mathrm{PrOH})$ & $-22.6^{\circ}(c 0.50,2-\mathrm{PrOH})$ \\
\hline
\end{tabular}

Fig. 4. $90 \mathrm{MHz}{ }^{13} \mathrm{C}$ NMR spectrum of concanamycin $\mathrm{A}$.

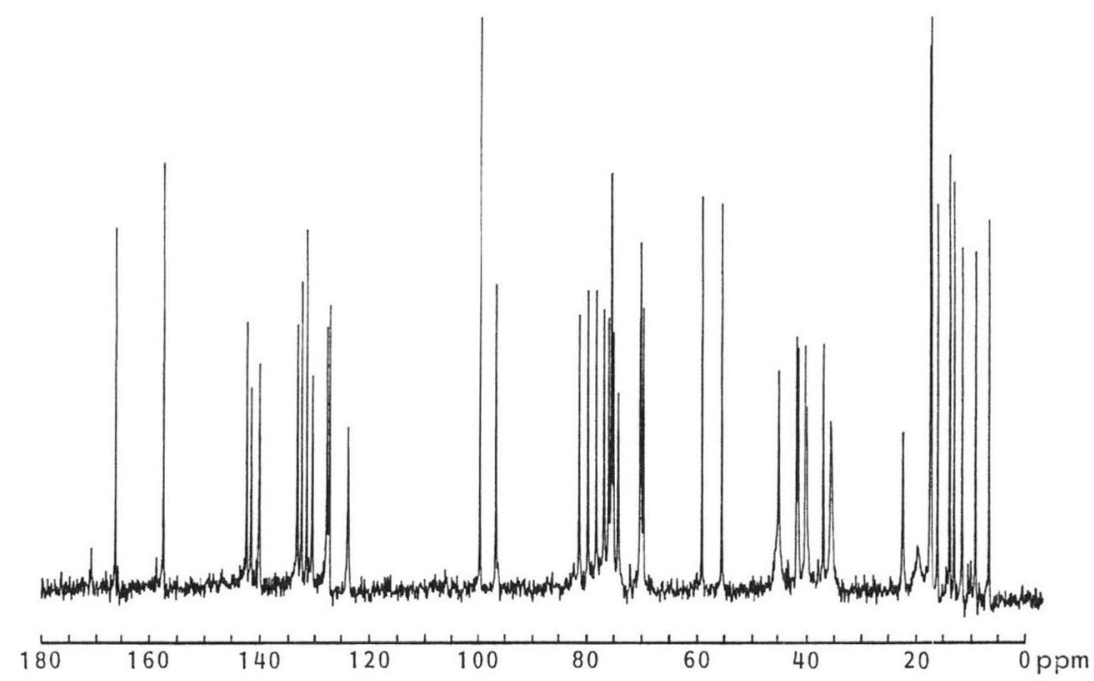

conjugated diene $(245 \mathrm{~nm})$. Concanamycin A crystallized from aqueous methanol as colorless thin plates, mp $162 \sim 163.5^{\circ} \mathrm{C}$. The elemental analysis did not allow an unambiguous deduction of the molecular formula as in the cases of other macrolide antibiotics. Therefore, the accurate molecular formula $\mathrm{C}_{46} \mathrm{H}_{75} \mathrm{NO}_{14}$ of concanamycin $\mathrm{A}$ was established on the basis of mass and ${ }^{13} \mathrm{C}$ NMR spectral analyses, and finally confirmed by the structure determination by chemical and spectroscopic methods. Namely, the in beam EI-MS gave a molecular ion at $m / z 865$, and the $90 \mathrm{MHz}{ }^{13} \mathrm{C}$ NMR spectrum (Fig. 4) indicated the presence of 46 carbon atoms although some carbon signals were very broad, perhaps because of the conformational flexibility of the macrolide ring. (All NMR spectra were measured at $50^{\circ} \mathrm{C}$ in $\mathrm{CDCl}_{3}$ with addition of $\mathrm{D}_{2} \mathrm{O}$ except otherwise described.) The ${ }^{13} \mathrm{C}$ NMR spectrum indicated ten $C$-methyl carbons $(\delta 6.9 \sim 17.6)$, ten methylene and methyne carbons $(\delta 19.8 \sim 45.0)$, two methoxy carbons ( $\delta 55.5$ and 59.1 ), ten oxymethyne carbons $(\delta 69.7 \sim 81.5)$, an acetal and a ketal carbons ( $\delta 96.6 \mathrm{~d}$ and $99.5 \mathrm{~s}$ ), ten olefinic carbons ( $\delta 123.6 \sim 142.1$ ), and a carbamoyl and an ester carbons ( $\delta 157.6 \mathrm{~s}$ and $166.3 \mathrm{~s}$ ). Since eight of ten olefinic carbons were assigned to an $\alpha, \beta, \gamma, \delta$-unsaturated ester and a conjugated diene, concanamycin A contains an isolated double bond. The acetal signal was assigned to the anomeric carbon of 4-carbamyl-2-deoxy- $\beta$-D-rhamnose and the ketal signal to C-21 of the six-membered hemiketal ring (see below). 
The $270 \mathrm{MHz}{ }^{1} \mathrm{H}$ NMR spectrum of concanaymcin A is shown in Fig. 5. The assignments of the proton signals could be accomplished by the aid of conventional proton spin decoupling, difference spectrum as well as NOE experiments, and are listed in Table 3. Before addition of $\mathrm{D}_{2} \mathrm{O}$, the spec-

Fig. 5. $270 \mathrm{MHz}{ }^{1} \mathrm{H}$ NMR spectrum of concanamycin A.

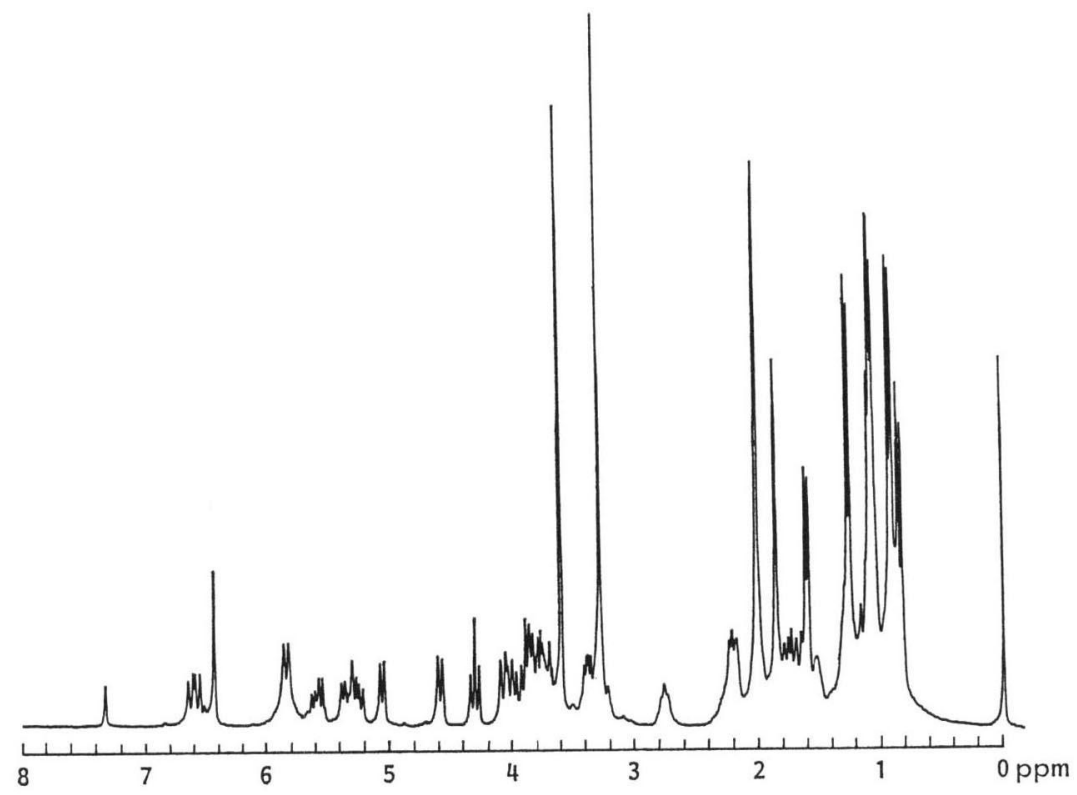

Table 3. ${ }^{1} \mathrm{H}$ NMR assignments of concanamycin $\mathrm{A}^{\mathrm{a}}$.

\begin{tabular}{|c|c|c|c|}
\hline $\mathrm{C} 2-\mathrm{OCH}_{3}$ & $3.57 \mathrm{~s}$ & H18 & $2.16 \mathrm{~m}$ \\
\hline $\mathrm{H} 3$ & $6.38 \mathrm{~s}$ & $\mathrm{C} 18-\mathrm{CH}_{3}$ & $0.83 \mathrm{~d}(7.0)$ \\
\hline $\mathrm{C} 4-\mathrm{CH}_{3}$ & $1.98 \mathrm{br} \mathrm{s}$ & H19 & $4.04 \mathrm{dd}(10.5,1.5)$ \\
\hline $\mathrm{H} 5$ & 5.80 br d (10.5) & $\mathrm{H} 20$ & $1.75 \mathrm{dq}(7.0,2.0)$ \\
\hline $\mathrm{H} 6$ & $2.73 \mathrm{~m}$ & $\mathrm{C} 20-\mathrm{CH}_{3}$ & $1.05 \mathrm{~d}(7.0)$ \\
\hline C6- $-\mathrm{CH}_{3}$ & $1.06 \mathrm{~d}(6.0)$ & $\mathrm{C} 22-\mathrm{H}_{2}$ & - \\
\hline $\mathrm{H} 7$ & $3.82 \mathrm{dd}(8.0,2.5)$ & $\mathrm{H} 23$ & $3.76 \mathrm{~m}$ \\
\hline $\mathrm{H} 8$ & $1.50 \mathrm{~m}$ & H24 & $1.25 \mathrm{~m}$ \\
\hline $\mathrm{C} 8-\mathrm{CH}_{2} \mathrm{CH}_{3}$ & $1.26 \mathrm{~m}$ & $\mathrm{C} 24-\mathrm{CH}_{3}$ & $0.89 \mathrm{~d}(6.6)$ \\
\hline $\mathrm{C} 8-\mathrm{CH}_{2} \mathrm{CH}_{3}$ & $0.88 \mathrm{t}(7.0)$ & $\mathrm{H} 25$ & $3.97 \mathrm{dd}(10.0,7.5)$ \\
\hline H9 & $3.25 \mathrm{brd}(11.0)$ & H26 & $5.31 \mathrm{ddq}(15.0,7.5,1.5)$ \\
\hline H10 & 2.20 obsc & $\mathrm{H} 27$ & $5.54 \mathrm{dq}(15.0,6.4)$ \\
\hline $\mathrm{C} 10-\mathrm{CH}_{3}$ & $1.05 \mathrm{obsc}$ & $\mathrm{C} 28-\mathrm{H}_{3}$ & $1.59 \mathrm{~d}(6.4)$ \\
\hline $\mathrm{C} 11-\mathrm{H}_{2}$ & $1.96 \mathrm{~m}$ & $\mathrm{H} 1^{\prime}$ & $4.55 \mathrm{dd}(9.0,1.5)$ \\
\hline $\mathrm{C} 12-\mathrm{CH}_{3}$ & $1.83 \mathrm{br} \mathrm{s}$ & $\mathrm{H} 2^{\prime} \mathrm{ax}$ & $1.65 \mathrm{~m}$ \\
\hline $\mathrm{H} 13$ & 5.80 br d (10.5) & $\mathrm{H} 2^{\prime} \mathrm{eq}$ & $2.17 \mathrm{~m}$ \\
\hline H14 & $6.54 \mathrm{dd}(15.0,10.5)$ & $\mathrm{H}^{\prime}{ }^{\prime}$ & $3.71 \mathrm{~m}$ \\
\hline H15 & $5.23 \mathrm{dd}(15.0,9.0)$ & $\mathrm{H} 4^{\prime}$ & $4.27 \mathrm{t}(9.3)$ \\
\hline H16 & $3.86 \mathrm{t}(9.0)$ & $\mathrm{H} 5^{\prime}$ & $3.35 \mathrm{dq}(9.3,6.0)$ \\
\hline $\mathrm{C} 16-\mathrm{OCH}_{3}$ & $3.26 \mathrm{~s}$ & $\mathrm{C} 6^{\prime}-\mathrm{H}_{3}$ & $1.24 \mathrm{~d}(6.0)$ \\
\hline H17 & 5.03 br d $(9.0)$ & $\mathrm{OCO}-\mathrm{NH}_{2}{ }^{\mathrm{b}}$ & $4.87 \mathrm{~s}$ \\
\hline
\end{tabular}

a Chemical shifts are in ppm downfield of internal TMS. Coupling constants in $\mathrm{Hz}$ are given in parentheses.

b Measured before addition of $\mathrm{D}_{2} \mathrm{O}$.

- Not determined.

obsc: Obscured (overlapping signals). 
trum indicated the presence of a carbamoyl group ( $\delta 4.87 \mathrm{~s}$ ), which was also ascertained by the IR spectrum (Fig. 6, $1718 \mathrm{~cm}^{-1}$ ) and the positive color reaction with chlorine-pyrazolinone-cyanide reagent. Extensive ${ }^{1} \mathrm{H}$ NMR analysis of the degradation products and concanamycin A itself revealed the gross structure of concanamycin A as shown in Fig. $1^{2,3)}$.

The ${ }^{1} \mathrm{H}$ NMR spectrum of $O$-methylconcanamycin A indicated the presence of three methoxy groups at $\delta 3.04,3.25$ and 3.67. This strongly suggested methylation of the hemiketal hydroxyl group, and this was further supported by the observed downfield shift of C-21 carbon at $\delta 99.5$ in the ${ }^{13} \mathrm{C}$ NMR spectrum of concanamycin A to $\delta 104.1$ for $O$-methylconcanamycin A.

Concanamycin B is an amorphous white powder. All attempts to crystallize the compound have failed so far. The physico-chemical properties of concanamycin B are very similar with those of concanamycin A. Since the molecular formula was deduced to be $\mathrm{C}_{45} \mathrm{H}_{73} \mathrm{NO}_{14}$ from the $\mathrm{FD}$ mass spectrum $\left(m / z 874, \mathrm{M}+\mathrm{Na}^{+}\right)$, concanamycin $\mathrm{B}$ is different from concanamycin A only by one methylene unit. The ${ }^{18} \mathrm{C}$ NMR and ${ }^{1} \mathrm{H}$ NMR spectra of concanamycin B are shown in Figs. 7 and 8 respectively, although some carbon signals at high field are not seen because of signal broadening. The IR

Fig. 6. IR spectrum of concanamycin $\mathrm{A}$ in $\mathrm{CHCl}_{3}$.

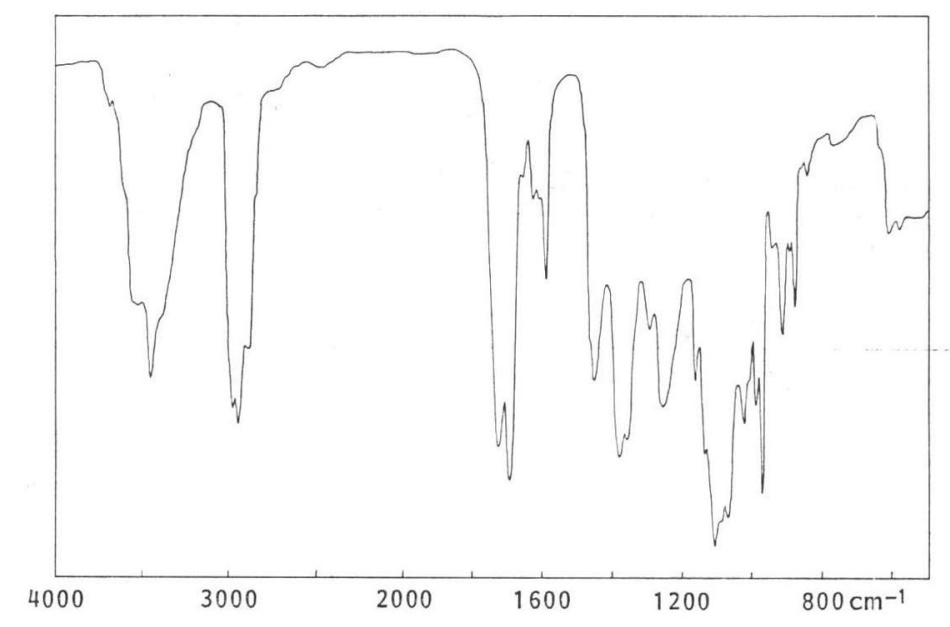

Fig. 7. $90 \mathrm{MHz}{ }^{13} \mathrm{C}$ NMR spectrum of concanamycin B.

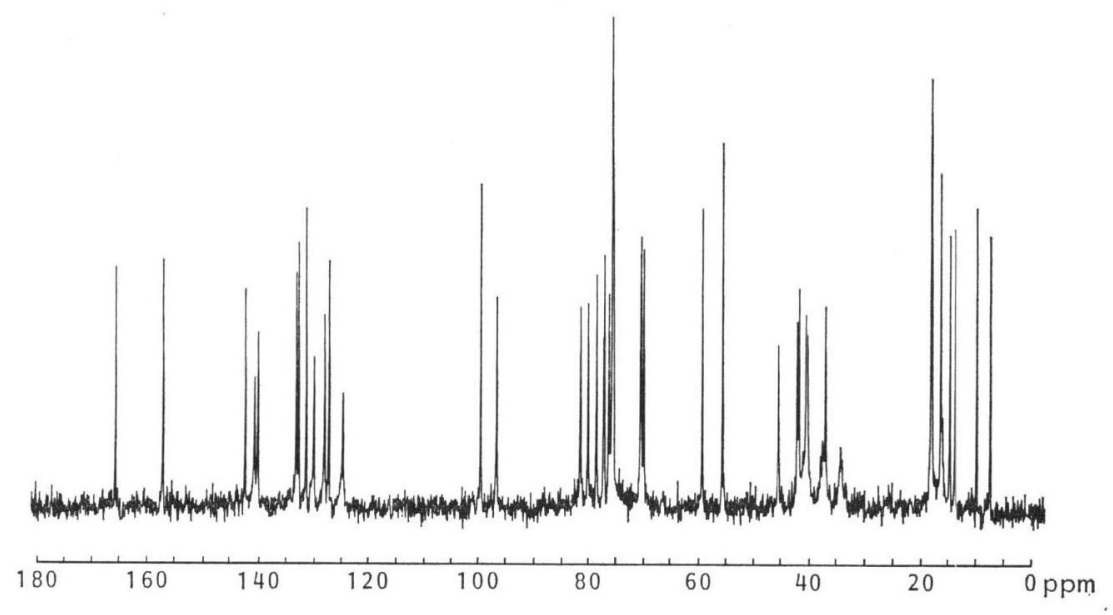


spectrum was almost identical with that of concanamycin A. Precise ${ }^{1} \mathrm{H}$ NMR analysis of concanamycin $\mathrm{B}$ and its degradation products revealed that an ethyl group attached to C-8 of concanamycin A was replaced by a methyl group in concanamycin $\mathrm{B}^{4)}$.

Concanamycin $\mathrm{C}$ crystallized from methanol as colorless thin plates, $\mathrm{mp} 153 \sim 155^{\circ} \mathrm{C}$ (the previously reported solvent for crystallization is corrected here). The molecular formula $\mathrm{C}_{45} \mathrm{H}_{74} \mathrm{O}_{13}$ was also deduced from the mass spectrum $\left(m / z 804, \mathrm{M}^{+}-\mathrm{H}_{2} \mathrm{O}\right)$. Concanamycin $\mathrm{C}$ is different from concanamycins $\mathrm{A}$ and $\mathrm{B}$ in the respect that it does not contain a nitrogen atom in the molecule. The ${ }^{13} \mathrm{C}$ NMR (Fig. 9), ${ }^{1} \mathrm{H}$ NMR (Fig. 10) and IR spectra (Fig. 11), and the negative color reaction with reagent the described above revealed the absence of a carbamoyl group in concanamycin $\mathrm{C}$, which was consistent with the molecular formula. Furthermore, the upfield-shifted signal of $\mathrm{H}-4^{\prime}(\delta 3.06 \mathrm{t}, J=$ $8.7 \mathrm{~Hz}$ ) of concanamycin $\mathrm{C}$ indicated decarbamylation of the hydroxyl group attached to C-4'.

\section{Biological Properties}

The effect of concanamycins on the proliferation of mouse splenic lymphocytes stimulated by concanavalin A was studied by the method used in screening and the result is shown in Fig. 12. Concanamycins A, B and C indicated 99,82 and $88 \%$ inhibition of the incorporation of $\left[{ }^{3} \mathrm{H}\right]$ thymidine into the cells respectively at the concentration of $1 \times 10^{-3} \mu \mathrm{g} / \mathrm{ml}$, and $99 \%$ or more inhibition at $3 \times$

Fig. 8. $270 \mathrm{MHz}^{1} \mathrm{H}$ NMR spectrum of concanamycin $\mathrm{B}$ in $\mathrm{CDCl}_{3}$ without addition of $\mathrm{D}_{2} \mathrm{O}$.

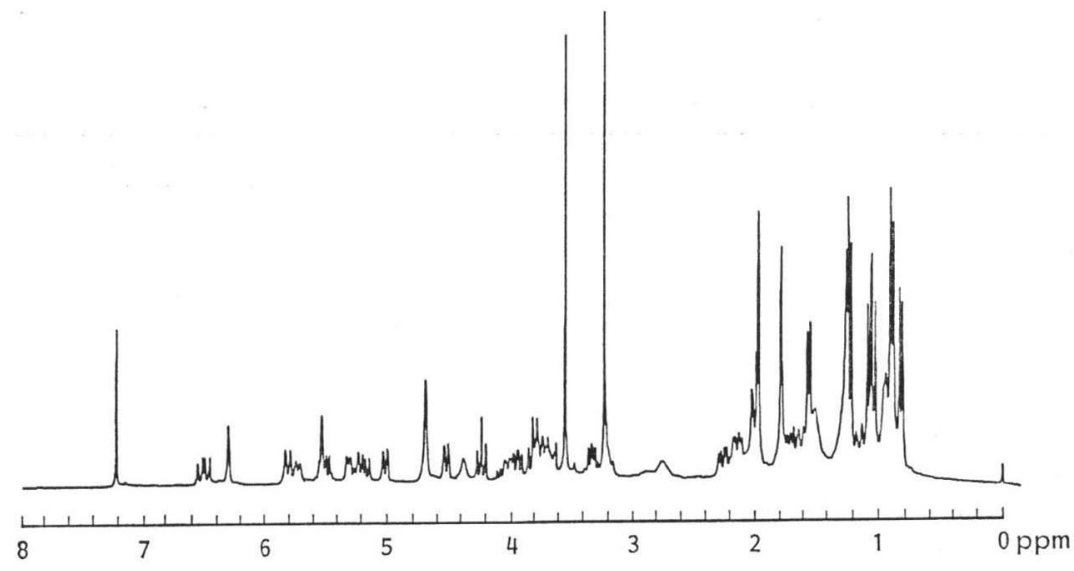

Fig. 9. $90 \mathrm{MHz}^{13} \mathrm{C}$ NMR spectrum of concanamycin C.

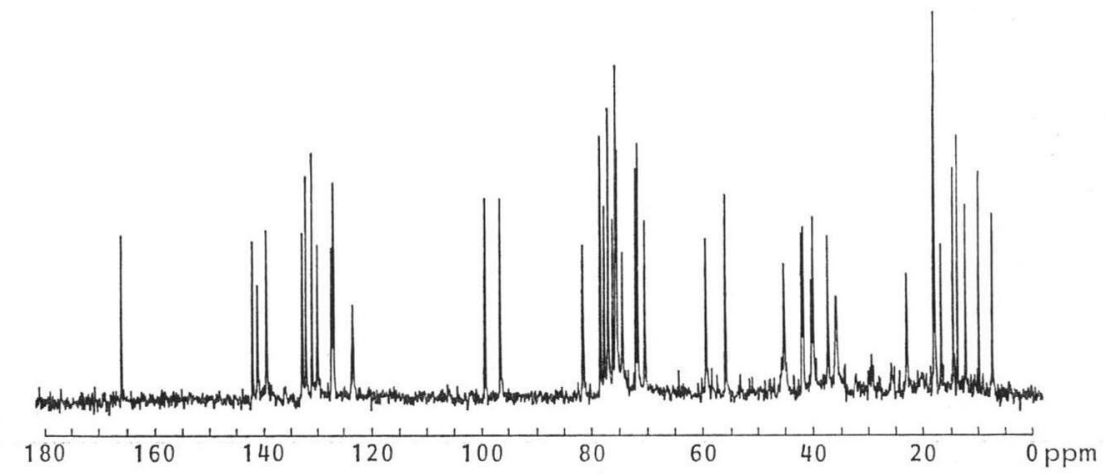


$10^{-3} \mu \mathrm{g} / \mathrm{ml}$. Since concanavalin A was considered to be a T-cell specific mitogen, we tested the effect of concanamycins on other types of mitogens. They also inhibited the proliferation of mouse splenic lymphocytes stimulated by pokeweed mitogen (B-cell mitogen) and mixed lymphocyte reaction ( $d d \mathrm{Y}$, nontreated; BALB/C, mitomycin C treated), respectively (unpublished results). These results suggested that the inhibition by these antibiotics was not specific for the stimulation by concanavalin $\mathrm{A}$.

Fig. 10. $270 \mathrm{MHz}{ }^{1} \mathrm{H}$ NMR spectrum of concanamycin $\mathrm{C}$.

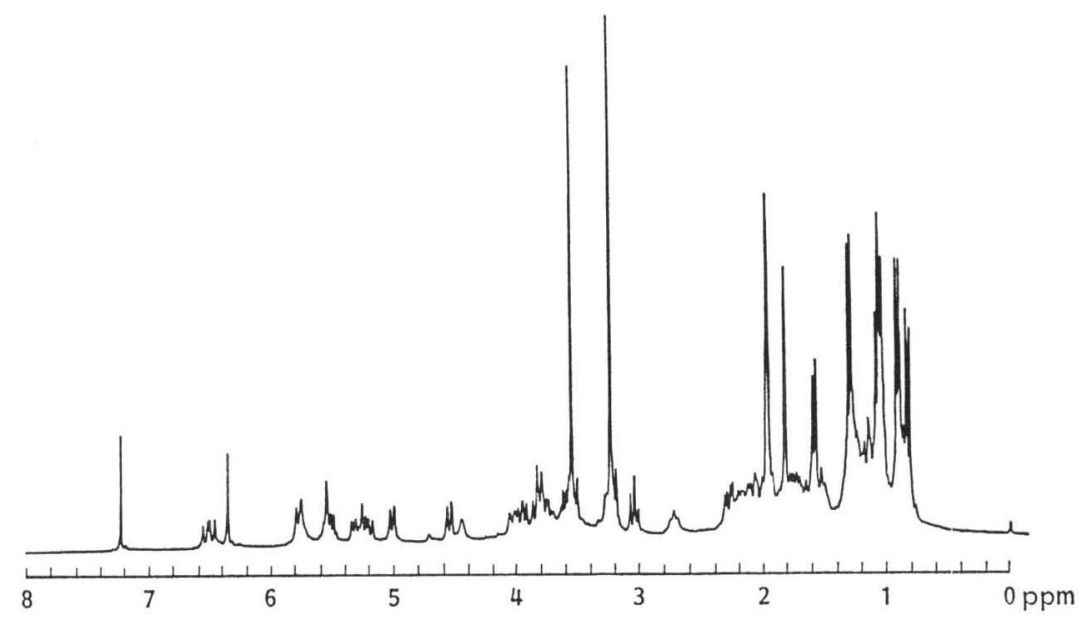

Table 4. Antimicrobial spectrum of concanamycins.

\begin{tabular}{|c|c|c|c|c|}
\hline & \multirow{2}{*}{ Media } & \multicolumn{3}{|c|}{$\mathrm{MIC}(\mu \mathrm{g} / \mathrm{ml})$} \\
\hline & & A & B & $\mathrm{C}$ \\
\hline Escherichia coli & 1 & $>100$ & $>100$ & $>100$ \\
\hline Bacillus subtilis & 1 & $>100$ & $>100$ & $>100$ \\
\hline B. cereus & 1 & $>100$ & $>100$ & $>100$ \\
\hline Micrococcus varians & 1 & $>100$ & $>100$ & $>100$ \\
\hline Proteus vulgaris & 1 & $>100$ & $>100$ & $>100$ \\
\hline Pseudomonas aeruginosa & 1 & $>100$ & $>100$ & $>100$ \\
\hline P. fluorescens & 1 & $>100$ & $>100$ & $>100$ \\
\hline Micrococcus luteus & 1 & $>100$ & $>100$ & $>100$ \\
\hline Serratia marcescens & 1 & $>100$ & $>100$ & $>100$ \\
\hline Staphylococcus aureus & 1 & $>100$ & $>100$ & $>100$ \\
\hline Mycobacterium phlei & 2 & $>100$ & 50 & $>100$ \\
\hline Candida albicans & 2 & $>100$ & $>100$ & $>100$ \\
\hline Kluyveromyces lactis & 2 & $>100$ & $>100$ & $>100$ \\
\hline Saccharomyces cerevisiae & 2 & $<0.39$ & $<0.39$ & $<0.39$ \\
\hline S. sake & 2 & $<0.39$ & $<0.39$ & $<0.39$ \\
\hline Alternaria citri & 2 & $<0.39$ & $<0.39$ & $<0.39$ \\
\hline Aspergillus niger & 2 & $>100$ & $>100$ & $>100$ \\
\hline Colletotichum coccodes & 2 & $>100$ & 12.5 & $>100$ \\
\hline Cryptococcus albidus & 2 & $>100$ & $>100$ & $>100$ \\
\hline Fusarium solani & 2 & $>100$ & $>100$ & $>100$ \\
\hline Pellicularia filamentosa & 2 & $>100$ & $>100$ & $>100$ \\
\hline Penicillium citrinum & 2 & 1.56 & 1.56 & 1.56 \\
\hline Piricularia oryzae & 2 & 25 & 25 & 25 \\
\hline Trichophyton asteroides & 2 & $>100$ & $>100$ & $>100$ \\
\hline
\end{tabular}

1: Nutrient agar, 2 : nutrient agar $+1 \%$ glucose. 
Fig. 11. IR spectrum of concanamycin $\mathrm{C}$ in $\mathrm{CHCl}_{3}$.

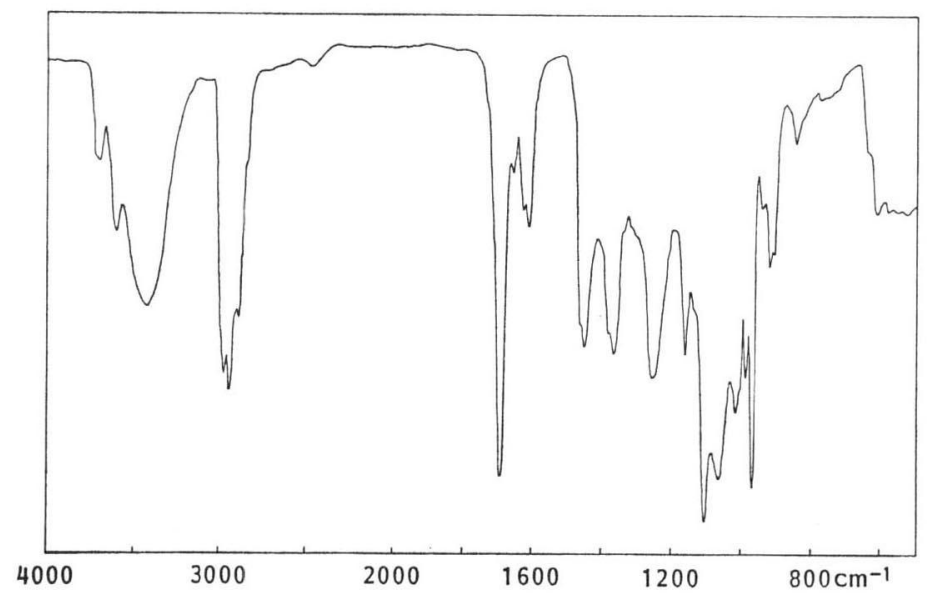

The antimicrobial activities of concanamycins were measured by agar dilution method and are listed in Table 4. All three components indicated the inhibitory activity against some of fungi and yeasts, but not against bacteria. In a preliminary incorporation experiment using Saccharomyces cerevisiae cell suspension and labeled precursors, DNA and RNA syntheses were inhibited in this order, but protein synthesis was not inhibited (unpulished result).

Acute toxicity was studied with $d d \mathrm{Y}$ mice. All of the mice survived intraperitoneal injection of $0.1 \mathrm{mg} / \mathrm{kg}$ of each component, but all of the mice died at the injection of $1.0 \mathrm{mg} / \mathrm{kg}$. Studies of other types of biological activities of concanamycins may prove interesting, because a related 16-membered macrocyclic lactone, L-681,110 was

Fig. 12. Effect of concanamycins on the proliferation of mouse splenic lymphocytes stimulated by concanavalin A.

- Concanamycin A, $\square \mathrm{B}, \triangle \mathrm{C}$. The samples were dissolved in $\mathrm{EtOH}$, and $5 \mu \mathrm{l}$ was added to each well of tissue culture plates. Each point represents the mean of quadruplicate measurement.

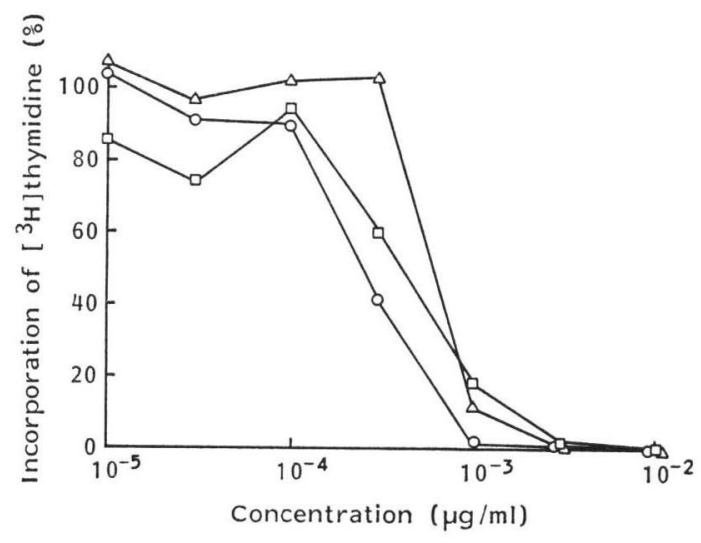

found as an inhibitor of the sodium and potassium ion activated adenosinetriphosphatase. ${ }^{7)}$

\section{Discussion}

Concanamycins A, B and C belong to a new class of 18-membered macrocyclic lactones* with a long side chain which incorporates a six-membered hemiketal ring having 2-deoxy- $\beta$-D-rhamnosyl group as a substituent. These were compared with other known antibiotics having some points of similarity in physical, chemical and biological properties. There are many antibiotics having similar UV spectra as those of concanamycins ( 285 and $245 \mathrm{~nm}$ ). Among them the antifungal antibiotics, folimycin $^{5)}$ and A-661-I ${ }^{6)}$, are the most similar to concanamycin A. Folimycin and A-661-I show UV absorption maxima at 245 and $284 \mathrm{~nm}$, and 246 and $285 \mathrm{~nm}$ respectively. Although the other physico-chemical properties of these two antibiotics described in the literature are somewhat different

* Concanamycins are the second example of the 18-membered macrolide antibiotics following borrelidin ${ }^{8)}$. 
from those of concanamycin A, direct comparison of these compounds on silica gel TLC revealed their identity. Furthermore, folimycin and A-661-I also gave the identical $O$-methyl derivative with that of concanamycin A by treating with $10^{-3} \mathrm{~N} \mathrm{HCl}$ - methanol; this supported the above conclusion. Recently, OMURA et al. reported the structural elucidation of virustomycin which has the identical aglycone with that of concanamycin A plus flavensomycinic acid attached to it ${ }^{9)}$. New 16-membered macrocyclic lactones, hygrolidin ${ }^{10)}$, bafilomycins ${ }^{11)}$ and L- $681,110^{7)}$ also contain an $\alpha, \beta, \gamma, \delta$-unsaturated lactone and a conjugated diene. Hagenmaier et al. reported the methylation of a hemiketal hydroxyl group in bafilomycins during the isolation procedure ${ }^{12)}$.

Concanamycin $\mathrm{B}$ also contains a nitrogen atom $\left(\mathrm{C}_{45} \mathrm{H}_{73} \mathrm{NO}_{14}\right)$ and is different from concanamycin $\mathrm{A}$ only by one methylene unit. Closely related with concanamycins $\mathrm{A}$ and $\mathrm{B}$ are ikutamycin ${ }^{13)}$, antibiotic 1-81d-1 $\mathrm{S}^{14)}$, scopathricin $\mathrm{II}^{15)}$, antibiotic PA $128^{18)}$, MD129-C2 ${ }^{17)}$, setamycin ${ }^{18)}$ and SF-1540 $A$ and $B^{18)}$. Particularly, scopathricin II is very similar with concanamycins $A$ and $B$ in the respect that it gave the 4-O-carbamate of methyl 2-deoxyrhamnoside by methanolysis. The latter three antibiotics seem to be different from concanamycins A and B, because they have a positive optical rotation. Kondo et al. also reported the formation of SF-1540 M by treating SF-1540 A with methanol ${ }^{20)}$. This compound seems to be formed by $O$-methylation of a hemiketal hydroxyl group of SF-1540 A. Since these related antibiotics have not been well characterized, the final conclusion about the identity of these antibiotics and concanamycins A and B is not possible until a direct comparison can be performed.

Concanamycin $\mathrm{C}$ differs from concanamycins $\mathrm{A}$ and $\mathrm{B}$ because it does not contain a nitrogen atom $\left(\mathrm{C}_{45} \mathrm{H}_{74} \mathrm{O}_{13}\right)$. At this point, concanamycin $\mathrm{C}$ is related to scopamycins $\mathrm{A}$ and $\mathrm{B}^{21)}$, scopathricin $\mathrm{I}^{15)}$, humidine ${ }^{22)}$ and neohumidine ${ }^{23)}$. In particular, scopathricin $\mathrm{I}$ is similar to concanamycin $\mathrm{C}$, since it gave methyl 2-deoxyrhamnoside by methanolysis. Scopamycin A is clearly distinguished from concanamycin $\mathrm{C}$ because it yielded $2-O$-methyl-L-rhamnose on treatment with acid $^{24)}$. It is very interesting that closely related antibiotics contain derivatives of $\mathrm{L}-$ and D-rhamnose. Further characterization of these antibiotics or direct comparison are necessary for identification.

\section{Acknowledgment}

We thank to Drs. K. Isono and S. SuzuKI, the Institute of Physical and Chemical Research, for providing the producing organism of concanamycins. We also thank to Drs. T. Higashijima, T. Miyazawa, K. FuriHATA, H. SETO and N. ŌTAKE, the University of Tokyo, for NMR spectra, and Dr. S. H.ARADA, Takeda Chemical Industries and Dr. J. ShoJI, Shionogi Research Laboratories, for the samples of folimycin and A-661-I, respectively.

\section{References}

1) Kinashi, H. \& K. Sakaguchi: Structures of antibiotics 2-11-A and B. Agric. Biol. Chem. 48: 245 247, 1984

2) Kinashi, H.; K. Someno, K. Sakaguchi, T. Higashijima \& T. Miyazawa: Alkaline degradation products of concanamycin A. Tetrahedron Lett. 22: 3857 3860, 1981

3) Kinashi, H.; K. Someno, K. Sakaguchi, T. Higashijima \& T. Miyazawa: Structure of concanamycin A. Tetrahedron Lett. 22: 3861 3864, 1981

4) Kinashi, H.; K. Sakaguchi, T. Higashijima \& T. Miyazawa: Structures of concanamycins B and C. J. Antibiotics 35: 1618 1620, 1982

5) Yamamoto, H.; K. Nakazawa, S. Hori \& A. Miyake: Studies on agricultural antibiotic. Folimycin, a new antibiotic produced by Streptomyces neyagawaensis nov. sp. Nippon Nogeikagaku Kaishi 34: $268 \sim 272,1960$

6) SHour, J. et al. (Shionogi): Method for preparation of new antibiotic, A-661-I. Japan Kokai 74-126,896, Dec. 4, 1974

7) Hensens, O. D.; R. L. Monaghan, L. Huang \& G. Albers-Schonberg: Structure of the sodium and potassium ion activated adenosinetriphosphatase inhibitor L-681,110. J. Am. Chem. Soc. 105: 3672 3679,1983

8) Keller-Schierlein, W.: Stoffwechselproducte von Mikroorganismen. 55. Uber die Konstitution des 
Borrelidins. Helv. Chim. Acta 50: 731 753, 1967

9) Ömura, S.; N. Imamura, K. Hinotozawa, K. Otoguro, G. Lukacs, R. Faghih, R. Tolmann, B. H. ARison \& J. L. SMIth: The structure of virustomycin A. J. Antibiotics 36: 1783 1786, 1983

10) Seto, H.; H. Akao, K. Furihata \& N. ŌTAKe: The structure of a new antibiotic, hygrolidin. Tetrahedron Lett. 23: $2667 \sim 2670,1982$

11) Werner, G.; H. Hagenmaier, K. Albert, H. Kohlshorn \& H. Drautz: The structure of the bafilomycins, a new group of macrolide antibiotics. Tetrahedron Lett. 24: 5193 5196, 1983

12) Werner, G.; H. Hagenmaier, H. Drautz, A. Baumgartner \& H. Zähner: Metabolic products of microorganisms. 224. Bafilomycins, a new group of macrolide antibiotics. Production, isolation, chemical structure and biological activity. J. Antibiotics 37: 110 117, 1984

13) Sakagami, Y.; A. Ueda \& S. Yamabayashi: Studies on ikutamycin, a new antifungal antibiotic. I. Isolation and properties of ikutamycin. J. Antibiotics, Ser. A 20: 299 303, 1967

14) Hermann, E. C.; L. M. Larson \& W. A. Price, Jr. (E.I. du Pont de Nemours \& Co.): Antibiotic and production thereof. US 2,805,185, Sept. 3, 1957

15) Takahashi, S.; J. B. McAlpine \& J. W. Corcoran: Scopathricins I and II: A preliminary report and possible correlation of scopamycin A. Abstracts Papers of 13th Intersci. Conf. on Antimicrob. Agents \& Chemother., No. 141, Washington D.C., 1973

16) RAo, K. V. \& J. E. LyNCH: PA 128, a new antiprotozoal antibiotic. Antibiot. Chemother. 8: 437 440, 1958

17) OKami, Y.; H. Umezawa \& M. Matsuoka (Inst. Microb. Chem.): Method for preparation of antibiotic, MD129-C2 substance. Japan Kokai 74-85,296, Aug. 15, 1974

18) Ōmura, S.; K. Otoguro, T. Nishikiori, R. Ōiwa \& Y. IwaI: Setamycin, a new antibiotic. J. Antibiotics 34: $1253 \sim 1256,1981$

19) Kondo, Y.; T. Shomura, H. Watanabe, Y. Suzuki, S. Inouye \& T. Niida: Studies on new antibiotics SF-1540 A and B substances. I. Producing microorganism, and isolation and physico-chemical and biological characterization. Sci. Reports of Meiji Seika Kaisha 17: 15 24, 1978

20) Kondo, Y.; K. Mryauchi \& S. InouYe: Studies on new antibiotics SF-1540 substance. II. Preparation and biological property of SF-1540 M, a new derivative of SF-1540 A substance. Sci. Reports of Meiji Seika Kaisha 18: 1 6, 1979

21) Hutter, R.; W. Keller-Schierlein, J. Nuesch \& H. Zähner: Stoffwechselprodukte von Mikroorganismen. 48. Scopamycine. Arch. Mikrobiol. 51: 1 8, 1965

22) Nakazawa, K.; M. Shibata, H. Yamamoto, T. Kanzaki \& E. Higashide: Studies on Streptomycetes. Humidine, an antifungal antibiotic produced by Streptomyces humidus. Nippon Nogeikagaku Kaishi 32: $713 \sim 716,1958$

23) Yamamoto, H.; T. Iwasa, M. Shibata, K. Mizuno \& A. Miyake: Streptomyces multispiralis nov. sp. and a new antibiotic, neohumidine. Agric. Biol. Chem. 29: 360 368, 1965

24) McAlpine, J. B. \& J. W. Corcoran: Scopamycin. II. Identification of the sugar moiety of scopamycin A as 2- $O$-methyl-L-rhamnose. J. Antibiotics 24: 51 56, 1971 